\title{
TEACHERS' PERCEPTION OF THEIR HEAD TEACHERS' ROLE EFFECTIVENESS
}

\section{ELIZABETH U. APEBENDE AND SAMSOM CYPRIAN USHIE}

(Received 21, February 2018; Revision Accepted 28, March 2018)

\begin{abstract}
This paper is a survey study focused on teacher's perception of their head teachers' role effectiveness. Two research hypotheses were formulated to guide the study. A seven item questionnaire was constructed and distributed to 100 teachers selected from primary schools in the South Senatorial District of Cross River State. A population t-test and an independent t-test was used to analyze the data. The result revealed a no significant perception of the head teachers' role effectiveness and a significant difference in perception between the private and public teachers with the private teachers having a positive perception of their teachers' role effectiveness. It was concluded that the head teachers should be more exposed to more re-training exercises to enable them do their job effectively.
\end{abstract}

\section{INTRODUCTION}

The position of the primary school teacher in the education development of the nation can never be over emphasized. Private individuals, communities as well as government have continued to put all their effort in building and equipping school with equipments and materials, but without the effort of qualified teachers to handle them, they remain worthless. The materials and equipments cannot use themselves. The pupils cannot teach themselves. Nwako (2009) noted that children cannot train themselves without the effort of teachers. To lay a sound and solid foundation for children in educational, life long and career development, qualified teachers are needed. The quality of whatever the child may become in future is laid at the primary school level. Teachers to handle children at this level must be of high quality. Ngada (2009) states that qualified teaching can take place easily with qualified, competent and well informed teachers. Ali (1992) noted that an educational system is only as good as the teachers who operate it. The National Policy on Education (2004) states that no education of any nation can rise above the quality of its teachers. Teachers are of prime importance to the education and development of any nation. They can make or mar the education development of the children under their care. The future of today's children is in the hands of today's teachers. Nkwodimmah (2003) affirms that the future of the nation rest in the hands of the teachers for quality and process today will inevitably be reflected in the citizens of tomorrow. The primary school teacher whose duty it is to transit quality education to children at their foundation level is supposed to undergo training to make him a qualified teacher. He should also possess the following characteristics:

i. A sound knowledge of subject matter.

ii. Ability to help students with their work.

iii. Appropriate subject matter presentation.

iv. Ability to motivate the student to learn

V. Fairness in preparing marking scheme and grading of examination (Nsor, 2009).

Apart from these a competent teacher should have the knowledge of the psychology of the child. He should have the ability to handle

Elizabeth U. Apebende, Department of Educational Foundations \& Administration, Cross River University of Technology (CRUTECH), Calabar, Nigeria.

Samsom Cyprian Ushie, Department of Curriculum and Teaching, University of Calabar, Calabar, Nigeria.

(C) 2018 Bachudo Science Co. Ltd. This work is licensed under Creative Commons Attribution 4.0 International license. 
and manipulate instructional materials and equipment. Also, he should have the knowledge of whom and for what grade or age a particular instructional material can be used. The teacher should have personal quality of love and patience to enable him work with the children.

The training the teacher gets from school may not be adequate after some years, because most ideas keep changing and being replaced by new ones. He must therefore go for retraining programmes such as workshops, seminars and conferences to refresh his memories and gain more knowledge. Okon (2005) state that after employment the primary school teacher should be exposed to series of in-service opportunities. Ogundale (2001) described teacher in-service as connoting the process for continuous updating of teachers' knowledge, skills and interest in their career. Another area where teachers can get more knowledge is supervision of instruction. This can be done either by supervisors from the Ministry of Education or the Head Teachers of each school.

The situation of the primary school teachers in Nigeria is very alarming. Many teachers are not effective because of the series of problems they have. They have problems such as poor salary which is most often not paid regularly. Poor classroom conditions with population of over 60 to 80 pupils in one classroom. Sometimes two to three teachers share one classroom. An important goal in any school or organization is to have satisfied workers who will remain happy on the job and put in all their best in order to achieve their goals. The head teacher in any school situation must therefore know the needs of staff and try as much as possible to motivate them. In this country, the primary school teacher are not regarded and not motivated. Ifeakor (2009) affirms that the Federal Government over the years have not addressed the plight of its teachers, most especially those in the primary school, in the area of adequate and prompt payment of salaries, the issue of fringe benefits for teachers are almost non-existent both in public and private sector of educational system. Maduewesi and Ihebereme (2009) are in support of the fact that teachers are generally dissatisfied with their jobs because of inadequate motivation. According to them teachers give flimsy reasons for being absent from school, they sell and carry out petty trading to supplement their income. Many look for jobs elsewhere and many have even left for other jobs.
Edemobi (2007) opined that if education in Nigeria is to survive, teachers who are responsible for helping students acquire knowledge, skill and practical orientation essential for self as well as for national development be effectively motivated. Apart from these, teachers are most often harassed by supervisors who visit the school in the name of supervision. Supervision of instruction that goes on in our schools today is not what is supposed to be. Supervisors come from the ministry with the aim of finding faults. Yanvare (2008) states that fault finding is one of those poor attitudes of supervisors, teachers dread so much. Teachers do not like supervision because of the way it is handled. They are often punished or threatened to be sacked from work because of one problem or the other. Ezeuwa (2005) states that instructional supervision is a support given by supervisors to teachers to bring about improvement in instructional process. Ejukwa (1999) also agreed that supervision is a support service given to teachers to enhance professional development. Unless supervisors change their way of approach to supervision, teachers may not grow professionally for the benefit of our children in their hands.

The researchers feel that the head teacher as a leader should have a better knowledge of his teachers and may have better understanding and approach to help his teachers grow professionally.

\section{The Head Teacher}

The Head Teacher is the sole administrator of the school. His duty according to Nwaka (2009) is to plan and equip the teachers with facilities, materials and equipment to make teaching and learning meaningful. Yalokwu (1991), states that the Head Teacher is an educational leader, an executor of educational policies, a counsellor and decision maker. As a leader, Ibiam (2005), states that he has the responsibility of effective planning, co-ordinating and control of human and material resources. Everything in the school is under his care and so has to look for ways of manipulating them to achieve the goals of the school as well as the educational goals of the nation.

Schools are built with the aim of transmitting knowledge to the young ones. The Head Teacher as a leader has to plan, direct and control the resources under his care to enable him achieve such goals or aims. Leadership hinges on activities of influencing people to strive 
willingly for group objectives. A good leader according to Fan \& Ekpe (2006) should fight for change by facing challenges arising from the attributes of informing, planning, organizing, designing, reforming, judging and evaluating.

The introduction of the Universal Basic Education (UBE) in Nigeria is aimed at eradicating illiteracy in the country. The world is changing rapidly with technological development here and there. What does the Head Teacher do in his own power to help eradicate illiteracy or help bring in technological development in his own domain? What can the Head Teacher do to help his teachers in their present problem? Ndu (1990), states that it is the Head Teacher who has direct contact with his staff that can detect the deviations and needs for staff development and training to increase performance. He went on to suggest that the Head Teacher should work hand in hand with the inspectorate division of the Ministry of Education.

The Head Teacher is a liaison officer between the government and his school. It is his place to take note of the problems in his school and report same to government. He knows the performance of his staff. He should know those who are effective, ineffective and those who are willing to work. He is also aware of their financial and family problems. It is his duty to notify government and recommend his staff for promotion and upgrading. He marks their lesson notes every day and supervises their teaching. He plans and makes arrangement for his staff to attend seminars, workshops and conferences. These can help to update the teacher's knowledge on recent changes and happenings in the field of teaching and learning. He holds regular meetings with his staff and sometimes the parents. In these meetings, the Head Teacher discusses with the teachers the mistakes he has often found them doing and other problems. The Head Teacher should involve other teachers in decision making. This can make the teachers feel that they belong to a group.

\section{Statement of the problem}

The persistent poor performance of most primary school pupils in public examination has become a course of concern in the society. This is because even at their final year many children cannot write their names or even read sign posts. Teachers, the government and even the parents have often been blamed for their inability to meet the demands of the pupils. Head Teachers are at the head of the primary school organization. They have the sole responsibility of planning, organizing and motivating teachers to work and so, teachers look up to them to help support and make them become successful in their teaching jobs. The question this study seeks to answer is: Does the Head Teachers' role effectiveness affect the general performance of his teachers? Specifically to what extent does this influence their performance?

\section{Research Questions}

1. What is the general teacher's perception of their Head Teachers role effectiveness?

2. Is there any significant difference in the perception of Head Teachers role effectiveness between teachers of public and private schools?

$\mathbf{H O}_{1}$ : The general perception of teacher's level of their Head Teachers' role effectiveness is not significantly high.

$\mathrm{HO}_{2}$ : There is no significant difference in the level of perception of their Head Teacher role effectiveness between public and private school teachers.

\section{Methodology}

The survey research design was adopted for this study. The population consisted of 2,554 primary school teachers sampled from 302 private and public primary school in Southern Senatorial District of Cross River State. The simple random sampling was used to gather the sample of 46 teachers from private schools and 54 teachers from public schools. A total of 100 teachers were used.

The research instrument was a Teacher Opinion Scale on Head Teachers Role Effectiveness Questionnaire (TOSHTREQ). This was made up of two sections. section "A" sought for information on personal data of respondents. Section "B" sought for information on Head Teachers Role Effectiveness. The instrument was validated by experts in test and measurement. The respondents were expected to indicate their opinion by making a tick $(\sqrt{ })$ on either of the scale of Strongly Agree (SA), Agree $(A)$, Disagree (D) and Strongly Disagree (SD).

\section{Data Collection/Analysis}

The researchers went to the different schools sampled and administered the instrument. All the instruments were returned. 
The statistical analysis used was the independent t-test and population t-test.

\section{RESULTS}

\section{Hypothesis One}

The general teacher's perception of their Head Teacher's role effectiveness is not significantly high. The main variable is sole effectiveness (which has seven components in the study).

The researchers reasoned that for the Head Teachers role effectiveness to be considered significantly high, their average score in each item should be significantly higher than the mid-point between Strongly Agree (scored 4) and Agree (scored 3) on the research instrument. This mid-point is 3.5. Therefore, hypothesis one can be restated as follows:

The Mean ( $x$ ) score representing the role effectiveness of Head Teachers is not significantly higher than 3.5 for each of the seven component or item.

The statistical analysis techniques used in testing this hypothesis was t-test of one sample mean, otherwise known as population ttest. The results of the analysis which were carried out are presented in Table 1.

Table 1: Results of Population t-tests Analysis of whether Teachers Perception of their Head Teachers Role Effectiveness is Significantly High ( $N=100)$

\begin{tabular}{lllll}
\hline \hline S/N & Role Effectiveness Components & $\mathrm{X}$ & $\mathrm{SD}$ & $\mathrm{t}$-obtained \\
\hline 1. & Ensuring preparation of lessons by teachers & 3.56 & 0.64 & $1.07^{\mathrm{a}}$ \\
2. & Ensuring the maintenance of general discipline & 3.45 & 0.69 & $-0.71^{\mathrm{a}}$ \\
3. & Ensuring the procurement/safety of facilities & 3.14 & 0.47 & $-7.20^{\mathrm{a}}$ \\
4. & Ensuring the general sanitation & 3.47 & 0.66 & $-0.42^{\mathrm{a}}$ \\
5. & Ensuring credible examinations & 3.18 & 0.66 & $-4.57^{\mathrm{a}}$ \\
6. & Ensuring teachers compliance on assessment & 3.41 & 0.69 & $-1.29^{\mathrm{a}}$ \\
& procedures & & & $-1.83^{\mathrm{a}}$ \\
7. & Ensuring the holding of regular meetings & 3.39 & 0.59 & $-1.83^{2}$ \\
\hline \hline
\end{tabular}

${ }^{a}$ Not significant at .05 alpha level, $d f=99$; Critical $t=1.98$

The results in Table 1 show that for each of the seven components of Head Teachers role effectiveness, the calculated $\mathrm{t}$-value is lower than the critical t-value of 1.98 at .05 level of significance with 99 degree of freedom. With these results, the null hypothesis is therefore retained in each of the seven instances.

The interpretation is that teacher's perception of their Head Teachers' Role effectiveness is not significantly positive.

\section{Hypothesis Two}

There is no significant difference between public and private school teachers' perception of their Head Teachers role effectiveness. To test this hypothesis, the independent t-test statistical analysis was used. The result is presented in Table 2 . 
Table 2: Independent t-test of the Difference between Public and Private Schools Teacher Perception of their Head Teachers' Role Effectiveness

\begin{tabular}{|c|c|c|c|c|c|c|}
\hline \multirow[t]{2}{*}{$\mathrm{S} / \mathrm{N}$} & \multirow[t]{2}{*}{ Role Effectiveness Components } & \multicolumn{2}{|c|}{$\begin{array}{l}\text { Public School } \\
(\mathrm{N}=54)\end{array}$} & \multicolumn{3}{|c|}{$\begin{array}{l}\text { Public School } \\
(\mathrm{N}=54)\end{array}$} \\
\hline & & $\mathrm{X}$ & SD & $\mathrm{x}$ & SD & t-obtained \\
\hline 1. & Ensuring preparation of lessons by teachers & 3.56 & 0.57 & 3.61 & 0.56 & $0.45^{\mathrm{a}}$ \\
\hline 2. & $\begin{array}{l}\text { Ensuring the maintenance of general } \\
\text { discipline }\end{array}$ & 3.05 & 0.84 & 3.55 & 0.83 & $3.33^{*}$ \\
\hline 3. & Ensuring the procurement/safety of facilities & 3.08 & 0.71 & 3.44 & 0.79 & $2.57^{*}$ \\
\hline 4. & Ensuring the general sanitation & 3.36 & 0.81 & 3.45 & 0.71 & $0.60^{a}$ \\
\hline 5. & Ensuring credible examinations & 3.16 & 0.92 & 3.35 & 0.63 & $1.26^{a}$ \\
\hline 6. & $\begin{array}{lcc}\text { Ensuring teachers } & \text { compliance } & \text { on } \\
\text { assessment procedures } & & \end{array}$ & 3.34 & 0.81 & 3.60 & 0.60 & $1.85^{\mathrm{a}}$ \\
\hline 7. & Ensuring the holding of regular meetings & 3.34 & 0.79 & 3.53 & 0.65 & $1.36^{a}$ \\
\hline
\end{tabular}

The results of the data analysis as presented in Table 2 shows that except for items 2 and 3 i.e. the role of ensuring the maintenance of general discipline and procurement/safety of school facilities respectively, the calculated $t-$ values of other items are lower than the critical or table $\mathrm{t}$-value of 1.98 at .05 level of significance and 98 degree of freedom. The null hypothesis is therefore retained for these five component items.

However, the null hypothesis is rejected in the cases of items 2 and 3 meaning that there is a significant difference between public and private school teachers' perception of their head teachers' role effectiveness.

Judging from the mean $(x)$ scores of the two groups under consideration, Table 2 further revealed that in all the components of head teachers' role effectiveness, the mean $(x)$ scores of private school teachers are greater than those of their counterparts in public schools.

The interpretation is that teachers of private schools have better perception of their head teachers' role effectiveness than public school teachers.

\section{DISCUSSION OF RESULTS}

Null hypothesis one seeking to know whether the teachers perception of their head teachers role effectiveness was significant a 0.05 significant level with a 99 degree of freedom tended towards the same direction of ineffectiveness. This was indicated by the mean scores and standard deviations ranging from 3.14 to 3.56 , and -0.42 to 1.07 respectively.
Items 1, 2, 4 and 6 having a mean score of $3.56,3.45,3.47$ and 3.41 with standard deviations of $0.64,0.69,0.66$ and 0.69 respectively indicated a high degree of ineffectiveness on the part of the head teachers.

This implied that the preparation of lessons for teaching the pupils, general discipline, sanitation and compliance with assessment procedures were worst hit. This could also substitute for poor teaching and learning loading poor performance by children in examinations. It is an indication to why some schools look dirty as well as their products not behaving well. Cases of pupils loitering the streets during school hours could be attributed to the ineffectiveness of the head teachers and hence the inability of the teachers to perform well their duties.

This result is consistent with that of Yalokwu (1991) who reported that the head teacher is an educational teacher, an administrator of educational policies, a counsellor and a decision maker. The teachers working under him, therefore look up to him for everything.

Hypothesis two indicated a significant difference between the role effectiveness of the two sets of school heads as regards discipline and facilities procurement and protection. This could be a function of management and not attitude of head teachers. Management may be lacking in motivational cues and of course the head teachers will not have any control over the teachers. In the case of public schools payment of salaries may be delayed, supply of equipment may not be there, what will one expect of the 
head teachers. The differences may be responsible for mass exodus of pupils by their parents to private school even if they did not meet the expected stands of the Government.

Items $1,4,5,6$ and 7 relating to preparation of lessons, school environment, examination, assessment and regular meeting indicated no difference between the head teachers of the two sets of schools. It implied that the head teachers attempting doing the same thing though at different degrees as can be adjudged by the variations in their mean scores and standard deviations. Summarily given a greater support by the stakeholders of the education industry, there may be no major differences between the two sets of head teachers.

This result supports that of Ibiam (2003) who found that sometimes the head teachers encounter problems with their teachers due to lack of cooperation and poor attitude to work. This is to say that since the teachers look up to the head teacher and cannot get what they expect they begin to show signs of misbehaviour.

\section{SUMMARY AND CONCLUSION}

The aim of this study was to find out teachers perception of their head teachers effectiveness. Two research hypotheses were formulated to guide the study. The result revealed that teachers' role effectiveness is not significantly positive and that the private school teachers have better perception of their head teachers' role effectiveness than teachers from public schools. It is therefore concluded that since the head teacher does not do his job well and does not encourage or motivate the teachers, the teachers tend to follow his footsteps by not doing their own job well.

\section{RECOMMENDATIONS}

Based on this result, the following recommendations were made:

1. There should be special retraining seminars and workshops organized for head teachers.

2. Head teacher should learn to have cordial relationship with their teachers. This they can do by having special interest in each of the teachers, knowing their individual problems and trying to help out where there is need.

3. The head teacher also should exercise his headship role by being strict over official things like regular marking of lesson notes and making sure that teachers teach effectively.

4. His leadership role should also show more discipline which can extend to both teachers and pupils.

5. Finally, the head teachers' role effectiveness can be seen from the way the environment is. Whether it is dirty or clean. He must insist on a clean environment always.

\section{REFERENCES}

Ali, H., 1992. Professionalism in Teacher Education in Nigerian Universities: Issues and Expectations. Oshodi: Nigeria Eudor Publishers.

Edemabi, U. D., 2007. Enhancing Secondary Education for Relevance and Sustainable National Development through Teacher Motivation. Knowledge Review 15, (27): 60-63.

Ejukwa, E. M., 1999. Adequate Supervision as a Means for Professional Development of Teachers in Nigeria. Journal of Educational Issues. Vol. 2(II), 215-222.

Fan, F. A and Ekpe, M. D., 2006. The Centrality of Effective Leadership and Followership in Group Dynamics. Journal of Research in National Development 4(2), 88-91.

Federal Republic of Nigeria., 2004. National Policy on Education $4^{\text {th }}$ Edition. NERDC Press.

Ibiam, J. U., 2003. The Role of Head Teachers in Managing Resources in Primary Schools. Journal of WCCI Nigeria Chapter. 4, (1):

Ibiam, J. U., The Role of Head Teachers in Managing Resources in Primary Schools. FORUM 4(1), 104-109.

Ifeakor, A. C., 2009. Monitoring and Evaluation of Universal Basic Education (UBE) in N. Ada, B. U. Maduewesi, and C. Ihebereme. Emergent Issues in the Universal Basic Education Programme in Nigeria, 278-296. 
Maduewesi, B. U and Ihebereme, C., 2009. Revisiting Teacher Motivation Strategies for Universal Basic Education Success in in N. Ada, B. U. Maduewesi, and C. Ihebereme. Emergent Issues in the Universal Basic Education Programme in Nigeria.

Mkwodimmah, M., 2003. Teacher Education for the $21^{\text {st }}$ Century. In A. O. ENoh (Ed.) Teacher Education and UBE.

Ndu, Alice., 1989/90. The Efficiency Goal in Human and Materials Resources Management in Nigeria. In a period of Economic Reconstruction in $A$. Adarlegbe (Ed.) Teacher Education for 63-3-4 System: The Management of Human and Material Resources for Education. Proceedings of the 1989 and 1990 conferences of the Nigeria Academy of Education.

Ngada, J. A., 2009. Teacher Quality: Antecedent to Quality Education and National Development. Nigerian Journal of Research and Production, 15(2), 13-19.

Nsor, E. E., 2009. Level of Teacher Involvement in Decision Making and Teacher Effectiveness in Public Secondary Schools in Northern Cross River State. The Calabar Counselor Vol.III(2), 204218.
Nwaka, G. N., 2009. Evolving and Vital Issues in School Administration of Universal Basic Education Programme in N. Ada, B. U. Maduewesi, and C. Ihebereme. Emergent Issues in the Universal Basic Education Programme in Nigeria. Onitsha: West \& Solomon Publishing Co. Ltd.

Ogunlade, A., 2001. Staff Development for Improved School Management. In N. A. Nwagwu, E. T. Ehiametalor, M. A. Ogunu, M. Nwadiani (Eds.) Current Issues in Educational Management in Nigeria. Benin City: Mabogun Publishers.

Okon, J. E and Ncharam, S. E., 2005. Human Resource Management and Primary Science Curriculum Implementation in Nigeria. The Forum: Journal of $\mathrm{WCCl}$ Nigeria Chapter, 5(1), 62-70.

Yalokwu, P. O., 1991. The Role of Head Teachers in Implementing Functional Education in Nigerian Schools. In S. U. Udo, G. O. Akpa \& P. Gang (Eds.) towards a Functional Primary School Education in Nigeria. Jos: Ehindero. 